\title{
Effects of Melatonin Treated Radish on the Growth of Following Stubble Lettuce under Salt Stress
}

\author{
Huan Yao ${ }^{1, a}$, Xun Wang ${ }^{2, b}$, Ming'an Liao ${ }^{1, c}$ and Lijin Lin ${ }^{2, d^{*}}$ \\ ${ }^{1}$ College of Horticulture, Sichuan Agricultural University, Chengdu, Sichuan, China \\ ${ }^{2}$ Institute of Pomology and Olericulture, Sichuan Agricultural University, Chengdu, Sichuan, China \\ a272365026@qq.com, b35744023@qq.com, Iman@sicau.edu.cn, dIlj800924@163.com \\ ${ }^{*}$ Corresponding author. Huan Yao and Xun Wang contributed equally to this work.
}

Keywords: Melatonin; Growth; Radish; Salt

Abstract: The effects of melatonin (MT) treated the previous stubble radish seedlings on the growth of following stubble lettuce seedlings under salt stress were studied by pot experiment. The results showed that MT increased the biomass, root volume, root length, plant height, chlorophyll content and carotenoid content of following stubble lettuce, but the effect was not significant. When the does of MT was $50 \mu \mathrm{mol} / \mathrm{L}$, these indexes got the maximums. With the increase of MT concentrations, the activities of SOD and CAT reduced, but the activity of POD improved first and then reduced. The maximum of POD activity was at $50 \mu \mathrm{mol} / \mathrm{L}$ of MT, which improved by $16.48 \%$ compared with the control. MT significantly increased the soluble protein content of following stubble lettuce compared with the control, and the maximum was at the concentration of $50 \mu \mathrm{mol} / \mathrm{L}$ of MT. Therefore, only 50 $\mu \mathrm{mol} / \mathrm{L}$ of MT treated the previous stubble radish could promote the growth of following stubble lettuce under salt stress.

\section{Introduction}

The melatonin (MT) is an important class of indole compounds, which is secreted by the pineal gland in the form of neuroendocrine hormone, a small molecule in animals [1]. It not only as a hormone exists in animals, but also removes a variety of free radicals from the body [2]. MT also can regulate the growth of plant by enhancing the ability of plants to resist various environmental stresses, and protect chlorophyll to enhance photosynthesis [3]. Under salt stress, MT can enhance the tolerance of plant to salt. The addition of $1 \mu \mathrm{mol} / \mathrm{L}$ MT can effectively increase the chlorophyll content of plant, and enhance its photosynthesis [4]. MT also increases the germination rate of cucumber seeds under salt stress, and significantly increases the activities of SOD, CAT and POD in cucumber seeds [5].

The effects of previous stubble crops on the growth of following stubble crops have been studied, and the effects of different crops were not the same. The previous stubble maize can promote the growth and development of following stubble cucumber [6], and the previous stubble garlic can promote the growth of roots and shoots of and following stubble crops [7].

Lettuce (Lactuca sativa L.) is one of the important green leafy vegetables, riches in vitamins, protein, sugar [8-9]. In this study, the effects of MT treated the previous stubble radish seedlings on the growth of following stubble lettuce seedlings under salt stress were studied, which could provide the reference for its application in vegetables.

\section{Materials and Methods}

Previous Stubble. The radish seedlings were transplanted in November 2015, and 5 concentrations $(0$, 50, 100, 150 and $200 \mu \mathrm{mol} / \mathrm{L}$ ) of MT with 3 replicates were sprayed on the leaves of plants, respectively. The Hogland nutrient solutions containing $50 \mathrm{mmol} / \mathrm{L} \mathrm{NaCl}$ were watered for two months.

Experimental Design. After radish seedlings harvest, the lettuce seedlings with three leaves expand were transplanted into each pot in January 2016. From the third day of transplanting, the Hogland nutrient solutions containing $50 \mathrm{mmol} / \mathrm{L} \mathrm{NaCl}$ were watered every two days, and $30 \mathrm{ml}$ solutions for 
each pot. When lettuce seedlings grow one month under salt stress, the upper mature leaves of lettuce seedlings were collected to determine the photosynthetic pigment (chlorophyll $a$, chlorophyll $b$ and total chlorophyll) contents [10]. The upper young leaves $(2 \mathrm{~cm}$ in length) were collected to determine the superoxide dismutase (SOD) activity, peroxidase (POD) activity, catalase (CAT) activity and soluble protein content [10]. Then, the whole plants were then gently removed, and the plant height, root length and root volume were measured. The roots and shoots were washed with tap water followed by deionized water, and the biomasses of root and shoot were measured.

Statistical Analyses. Statistical analyses were conducted using SPSS 13.0 statistical software (IBM, Chicago, IL, USA). Data were analyzed by one-way analysis of variance with Duncan's multiple range test $(\mathrm{p}=0.05$ confidence level).

\section{Results and Discussion}

Biomass of Following Stubble Lettuce. The root, shoot and whole plant biomasses of following stubble lettuce increased in the all treatments of MT compared with the control (Table 1). The shoot and whole plant biomass of following stubble lettuce was ranked as: $50 \mu \mathrm{mol} / \mathrm{L}>150 \mu \mathrm{mol} / \mathrm{L}>100$ $\mu \mathrm{mol} / \mathrm{L}>200 \mu \mathrm{mol} / \mathrm{L}>0 \mu \mathrm{mol} / \mathrm{L}$. When the doses of MT were 50, 100, 150 and $200 \mu \mathrm{mol} / \mathrm{L}$, the root biomass of following stubble lettuce increased by 23.08\% ( $p<0.01), 4.62 \%(p>0.05), 27.69 \%(p<$ $0.01)$ and $18.46 \%(0.01<p<0.05)$ respectively compared with the control, shoot biomass increased by $11.29 \%(p>0.05), 4.19 \%(p>0.05), 6.01 \%(p>0.05)$ and $1.82 \%(p>0.05)$ respectively, and whole plant increased by $12.54 \%(0.01<p<0.05), 4.23 \%(p>0.05), 8.14 \%(0.01<p<0.05)$ and $3.58 \%(p>0.05)$ respectively. Therefore, MT increased the growth of following stubble lettuce, which was suitable for enhancing the yield of following stubble lettuce.

Table 1 The biomass of following stubble lettuce

\begin{tabular}{|c|c|c|c|}
\hline $\begin{array}{c}\text { MT concentrations } \\
(\mu \mathrm{mol} / \mathrm{L})\end{array}$ & $\begin{array}{c}\text { Root } \\
(\mathrm{g} / \text { plant })\end{array}$ & $\begin{array}{c}\text { shoot } \\
(\mathrm{g} / \mathrm{plant})\end{array}$ & $\begin{array}{c}\text { Whole plant } \\
(\mathrm{g} / \mathrm{plant})\end{array}$ \\
\hline 0 & $0.65 \pm 0.03 \mathrm{bC}$ & $5.49 \pm 0.69 \mathrm{aA}$ & $6.14 \pm 0.16 \mathrm{bA}$ \\
\hline 50 & $0.80 \pm 0.04 \mathrm{aAB}$ & $6.11 \pm 0.40 \mathrm{aA}$ & $6.91 \pm 0.08 \mathrm{aA}$ \\
\hline 100 & $0.68 \pm 0.04 \mathrm{bBC}$ & $5.72 \pm 0.42 \mathrm{aA}$ & $6.40 \pm 0.25 \mathrm{bA}$ \\
\hline 150 & $0.83 \pm 0.05 \mathrm{aA}$ & $5.82 \pm 0.23 \mathrm{aA}$ & $6.64 \pm 0.26 \mathrm{aA}$ \\
\hline 200 & $0.77 \pm 0.01 \mathrm{aABC}$ & $5.59 \pm 0.50 \mathrm{aA}$ & $6.36 \pm 0.11 \mathrm{bA}$ \\
\hline
\end{tabular}

Different lowercase letters within a column indicate significant difference (one-way analysis of variance followed by Duncan's multiple range test; $p<0.05$ ). The same as following tables.

Root Length and Plant Height of Following Stubble Lettuce. MT promoted the growth of following stubble lettuce root, and increased the root length and volume of following stubble lettuce (Table 1). The root length of following stubble lettuce was ranked as: $150 \mu \mathrm{mol} / \mathrm{L}>200 \mu \mathrm{mol} / \mathrm{L}>50$ $\mu \mathrm{mol} / \mathrm{L}>100 \mu \mathrm{mol} / \mathrm{L}>0 \mu \mathrm{mol} / \mathrm{L}$. When the doses of MT were 50, 100, 150 and $200 \mu \mathrm{mol} / \mathrm{L}$, the root length of following stubble lettuce increased by $10.78 \%(p>0.05), 0.82 \%(p>0.05), 18.52 \%(p>$ $0.05)$ and $17.94 \%(p>0.05)$ respectively compared with the control. The root volume also increased by MT treatments, and order was the same as root length. When the doses of MT were 50, 100, 150 and $200 \mu \mathrm{mol} / \mathrm{L}$, the root volume of following stubble lettuce increased by $28.57 \%(p<0.01), 11.11 \%$ $(0.01<p<0.05), 31.75 \%(p<0.01)$ and $31.75 \%(p<0.01)$ respectively compared with the control. The plant height increased with the increase of MT concentrations when the dose of was not more than $150 \mu \mathrm{mol} / \mathrm{L}$, and decreased when the dose of MT was more than $150 \mu \mathrm{mol} / \mathrm{L}$. When the doses of MT were 50,100, 150 and $200 \mu \mathrm{mol} / \mathrm{L}$, the root length of following stubble lettuce increased by $2.63 \%$ $(p>0.05), 2.88 \%(p>0.05), 8.48 \%(p>0.05)$ and $1.23 \%(p>0.05)$ respectively compared with the control.

Chlorophyll Content in Following Stubble Lettuce. MT treatments decreased the chlorophyll content in leaves of following stubble lettuce, but the effect was not significant (Table 3). The contents of chlorophyll $a$ and total chlorophyll were ranked as: $0 \mu \mathrm{mol} / \mathrm{L}>100 \mu \mathrm{mol} / \mathrm{L}>200 \mu \mathrm{mol} / \mathrm{L}>150$ 
$\mu \mathrm{mol} / \mathrm{L}>50 \mu \mathrm{mol} / \mathrm{L}$. When the doses of MT were 50, 100, 150 and $200 \mu \mathrm{mol} / \mathrm{L}$, the chlorophyll $a$ content of following stubble lettuce decreased by $10.81 \%(p>0.05), 2.70 \%(p>0.05), 5.41 \%(p>$ $0.05)$ and $4.05 \%(p>0.05)$ respectively compared with the control, and the total chlorophyll content decreased by $10.75 \%(p>0.05), 2.15 \%(p>0.05), 5.38 \%(p>0.05)$ and $4.30 \%(p>0.05)$ respectively compared with the control. The carotenoids content was decreased by MT compared with the control, too (Table 3).

Table 2 The root length and plant height of following stubble lettuce

\begin{tabular}{|c|c|c|c|}
\hline $\begin{array}{c}\text { MT concentrations } \\
(\mu \mathrm{mol} / \mathrm{L})\end{array}$ & $\begin{array}{c}\text { Root length } \\
(\mathrm{cm})\end{array}$ & $\begin{array}{c}\text { Root volume } \\
(\mathrm{ml})\end{array}$ & $\begin{array}{c}\text { Plant height } \\
(\mathrm{cm})\end{array}$ \\
\hline 0 & $12.15 \pm 1.99 \mathrm{aA}$ & $0.63 \pm 0.01 \mathrm{cB}$ & $12.15 \pm 0.94 \mathrm{aA}$ \\
\hline 50 & $13.45 \pm 1.67 \mathrm{aA}$ & $0.81 \pm 0.03 \mathrm{aA}$ & $12.47 \pm 0.61 \mathrm{aA}$ \\
\hline 100 & $12.25 \pm 2.07 \mathrm{aA}$ & $0.70 \pm 0.02 \mathrm{bB}$ & $12.50 \pm 0.68 \mathrm{aA}$ \\
\hline 150 & $14.40 \pm 2.57 \mathrm{aA}$ & $0.83 \pm 0.05 \mathrm{aA}$ & $13.18 \pm 0.98 \mathrm{aA}$ \\
\hline 200 & $14.33 \pm 1.85 \mathrm{aA}$ & $0.83 \pm 0.02 \mathrm{aA}$ & $12.30 \pm 1.22 \mathrm{aA}$ \\
\hline
\end{tabular}

Table 3 The chlorophyll content in following stubble lettuce

\begin{tabular}{|c|c|c|c|c|}
\hline $\begin{array}{c}\text { MT } \\
\text { concentrations } \\
(\mu \mathrm{mol} / \mathrm{L})\end{array}$ & $\begin{array}{c}\text { Chlorophyll } a \\
(\mathrm{mg} / \mathrm{g})\end{array}$ & $\begin{array}{c}\text { Chlorophyll } b \\
(\mathrm{mg} / \mathrm{g})\end{array}$ & $\begin{array}{c}\text { Total chlorophyll } \\
(\mathrm{mg} / \mathrm{g})\end{array}$ & $\begin{array}{c}\text { Carotenoids } \\
(\mathrm{mg} / \mathrm{g})\end{array}$ \\
\hline 0 & $0.74 \pm 0.00 \mathrm{aA}$ & $0.15 \pm 0.00 \mathrm{aA}$ & $0.93 \pm 0.00 \mathrm{aA}$ & $0.26 \pm 0.00 \mathrm{aA}$ \\
\hline 50 & $0.66 \pm 0.03 \mathrm{aA}$ & $0.13 \pm 0.01 \mathrm{aA}$ & $0.83 \pm 0.04 \mathrm{aA}$ & $0.23 \pm 0.01 \mathrm{aA}$ \\
\hline 100 & $0.72 \pm 0.05 \mathrm{aA}$ & $0.15 \pm 0.01 \mathrm{aA}$ & $0.91 \pm 0.07 \mathrm{aA}$ & $0.25 \pm 0.02 \mathrm{aA}$ \\
\hline 150 & $0.70 \pm 0.03 \mathrm{aA}$ & $0.14 \pm 0.01 \mathrm{aA}$ & $0.88 \pm 0.04 \mathrm{aA}$ & $0.24 \pm 0.01 \mathrm{aA}$ \\
\hline 200 & $0.71 \pm 0.01 \mathrm{aA}$ & $0.14 \pm 0.00 \mathrm{aA}$ & $0.89 \pm 0.01 \mathrm{aA}$ & $0.24 \pm 0.00 \mathrm{aA}$ \\
\hline
\end{tabular}

Antioxidant Enzyme Activity of Following Stubble Lettuce. MT reduced the SOD and CAT activities of following stubble lettuce in all treatments compared with the control (Table 4). The SOD activity of following stubble lettuce was ranked as: $0 \mu \mathrm{mol} / \mathrm{L}>50 \mu \mathrm{mol} / \mathrm{L}>100 \mu \mathrm{mol} / \mathrm{L}>150$ $\mu \mathrm{mol} / \mathrm{L}>200 \mu \mathrm{mol} / \mathrm{L}$. When the doses of MT were 50, 100, 150 and $200 \mu \mathrm{mol} / \mathrm{L}$, the SOD activity of following stubble lettuce reduced by $16.05 \%(p<0.01), 23.69 \%(p<0.01), 31.02 \%(p<0.01)$ and $33.28 \%(p<0.01)$ respectively compared with the control. The CAT activity of following stubble lettuce was ranked as: $0 \mu \mathrm{mol} / \mathrm{L}>100 \mu \mathrm{mol} / \mathrm{L}>50 \mu \mathrm{mol} / \mathrm{L}>150 \mu \mathrm{mol} / \mathrm{L}>200 \mu \mathrm{mol} / \mathrm{L}$. When the doses of MT were 50, 100, 150 and $200 \mu \mathrm{mol} / \mathrm{L}$, the CAT activity of following stubble lettuce reduced by $19.97 \%(p<0.01), 19.91 \%(p<0.01), 36.93 \%(p<0.01)$ and $38.68 \%(p<0.01)$ respectively compared with the control. The POD activity of following stubble lettuce was ranked as: $50 \mu \mathrm{mol} / \mathrm{L}>$ $0 \mu \mathrm{mol} / \mathrm{L}>150 \mu \mathrm{mol} / \mathrm{L}>100 \mu \mathrm{mol} / \mathrm{L}>200 \mu \mathrm{mol} / \mathrm{L}$. When the dose of MT was $50 \mu \mathrm{mol} / \mathrm{L}$, the POD activity of following stubble lettuce improved by $16.48 \%(p<0.01)$ compared with the control; When the doses of MT were 100, 150 and $200 \mu \mathrm{mol} / \mathrm{L}$, the POD activity of following stubble lettucereduced by $3.20 \%(p>0.05), 0.97 \%(p>0.05)$ and $15.92 \%(p<0.01)$ respectively compared with the control. MT increased the soluble protein content of following stubble lettuce in all treatments compared with the control (Table 4). The ranked of soluble protein content was ranked as: $50 \mu \mathrm{mol} / \mathrm{L}>150 \mu \mathrm{mol} / \mathrm{L}>$ $200 \mu \mathrm{mol} / \mathrm{L}>100 \mu \mathrm{mol} / \mathrm{L}>0 \mu \mathrm{mol} / \mathrm{L}$. When the doses of MT were 50, 100, 150 and $200 \mu \mathrm{mol} / \mathrm{L}$, the soluble protein content of following stubble lettuce increased by $196.59 \%(p<0.01), 8.52 \%(p>0.05)$, $151.82 \%(p<0.01)$ and $16.79 \%(p>0.05)$ respectively compared with the control.

\section{Conclusions}

MT treated the previous stubble radish seedlings increased the biomass, root volume, root length, plant height, chlorophyll content and carotenoid content of following stubble lettuce seedlings under salt stress, but the effect was not significant. When the does of MT was $50 \mu \mathrm{mol} / \mathrm{L}$, these indexes got the maximums. With the increase of MT concentrations, the activities of SOD and CAT reduced, but the 
activity of POD improved first and then reduced. The maximum of POD activity was at $50 \mu \mathrm{mol} / \mathrm{L}$ of MT compared with the control. MT significantly increased the soluble protein content of following stubble lettuce compared with the control, and the maximum was at the concentration of $50 \mu \mathrm{mol} / \mathrm{L}$ of MT. Therefore, only $50 \mu \mathrm{mol} / \mathrm{L}$ of MT treated the previous stubble radish could promote the growth of following stubble lettuce under salt stress.

Table 4 The antioxidant enzyme activity of following stubble lettuce

\begin{tabular}{|c|l|l|l|l|}
\hline $\begin{array}{c}\text { MT concentrations } \\
(\mu \mathrm{mol} / \mathrm{L})\end{array}$ & \multicolumn{1}{|c|}{$\begin{array}{c}\text { POD activity } \\
(\mathrm{U} / \mathrm{g} / \mathrm{min})\end{array}$} & $\begin{array}{c}\text { SOD activity } \\
(\mathrm{U} / \mathrm{g})\end{array}$ & $\begin{array}{c}\text { CAT activity } \\
(\mathrm{mg} / \mathrm{g} / \mathrm{min})\end{array}$ & $\begin{array}{c}\text { Soluble } \\
\text { protein } \\
\text { content }(\mathrm{mg} / \mathrm{g})\end{array}$ \\
\hline 0 & $93.40 \pm 0.49 \mathrm{bB}$ & $116.65 \pm 7.20 \mathrm{aA}$ & $18.28 \pm 0.23 \mathrm{aA}$ & $4.11 \pm 0.03 \mathrm{bB}$ \\
\hline 50 & $108.79 \pm 1.55 \mathrm{aA}$ & $97.93 \pm 1.14 \mathrm{bB}$ & $14.63 \pm 0.57 \mathrm{bB}$ & $12.19 \pm 1.44 \mathrm{aA}$ \\
\hline 100 & $90.41 \pm 1.55 \mathrm{bB}$ & $89.02 \pm 1.99 \mathrm{bcBC}$ & $14.64 \pm 0.45 \mathrm{bB}$ & $4.46 \pm 0.19 \mathrm{bB}$ \\
\hline 150 & $92.49 \pm 0.94 \mathrm{bB}$ & $80.47 \pm 2.98 \mathrm{cdC}$ & $11.53 \pm 0.43 \mathrm{cC}$ & $10.35 \pm 0.91 \mathrm{aA}$ \\
\hline 200 & $78.53 \pm 3.28 \mathrm{cC}$ & $77.83 \pm 1.31 \mathrm{dC}$ & $11.21 \pm 0.12 \mathrm{cC}$ & $4.80 \pm 0.90 \mathrm{bB}$ \\
\hline
\end{tabular}

\section{Acknowledgements}

This work was financially supported by the Undergraduate Thesis Breeding Program of Sichuan Agricultural University (2015).

\section{References}

[1] Y. Zhao, D.H. Wang and X.Y. Zhao: Acta Botanica Boreali-Occidentalia Sinica Vol. 34 (2014), p. 196. (In Chinese)

[2] N. Zhang, H.J. Zhang, R.C. Yang, W.Y. Huang and Y.D. Guo: Chinese Agricultural Science Bulletin Vol. 28 (2012), p. 16. (In Chinese)

[3] H.Y. Pan, X.Q. Zhang, J. Li, J. Zhao and H.Y. Bu: Journal of Northwest University (Natural Science Edition) Vol. 43 (2013), p. 238. (In Chinese)

[4] C. Li, P. Wang, Z. Wei, D. Liang, C. Liu, L. Yin, D. Jia, M. Fu and F. Ma: Journal of Pineal Research Vol. 53 (2012), p. 298.

[5] H.J. Zhang, N. Zhang, R.C. Yang, L. Wang, Q.Q. Sun, D.B. Li and Y.D. Guo: Journal of Pineal Research Vol. 57 (2014), p. 269.

[6] H.X. You, Y.L. Liang, W. Lv, Z.J. Chen, S.N. Du and F.L. Xu: Journal of Northwest A\&F University (Natural Science Edition) Vol. 34 (2006), p. 101. (In Chinese)

[7] Y.L. Zhou, Z.H. Cheng and H.W. Meng: Chinese Journal of Applied Ecology Vol. 18 (2007), p. 81. (In Chinese)

[8] Y. Yan, B. Lei, L.W. Wang and Z.L. Bie: Journal of Changjiang Vegetables Vol. 24 (2010), p. 39. (In Chinese)

[9] W.H. Chen, Z.G. Xu, X.Y. Liu, Y. Yang, Z.M. Wang and F.F. Song: Acta Botanica Boreali-Occidentalia Sinica Vol. 31 (2011), p. 1434. (In Chinese)

[10]Z.B. Hao, J. Cang and Z. Xu: Plant Physiology Experiment (Harbin Institute of Technology Press, Harbin, China 2004). (In Chinese) 